\title{
STRATEGI PEMBERDAYAAN UMKM BERBASIS PKK DI DESAWISATA SEKAPUK KABUPATEN GRESIK
}

\author{
Yuli Ermawati \\ Universitas Wijaya Putra Surabaya \\ Pujianto \\ Universitas Wijaya Putra Surabaya
}

\begin{abstract}
Purpose of this study is to explore information about financial governance, policies and empowerment systems carried out by the relevant village government, map the constraints of implementing MSME empowerment in the Tourism Village area, then make the right pattern/model for empowering MSMEs in the Tourism Village area in Gresik Regency. The method used in this research is qualitative in the hope of digging deeper into the information needed to answer the objectives of the research. The object of this research is Sekapuk Gresik Village, which is known as the billionaire village. The results showed that the empowerment of MSMEs in Sekapuk Tourism Village came from the independent management of the PKK. The synergy between the PKK and the Village Government is a milestone in the independence of the MSME empowerment policy and management system. The role of the Village Government is to provide facilities and stimulation for the independence of the sustainability of MSMEs under the PKK. The profitsharing system is an effective way to encourage the growth of MSMEs which is synergized with the management of tourist areas
\end{abstract}

Keywords: MSME Empowerment Model, Tourism Village

Paper type: Research paper

*Corresponding author: yuliermawati@uwp.ac.id

Received: October 06, 2021; Accepted: November 13, 2021; Available online: December, 06, 2021

Cite this document:

Ermawati, Y., \& Pujianto. (2021). Strategi Pemberdayaan UMKM Berbasis PKK di Desa Wisata Sekapuk Kabupaten Gresik. Jurnal Masharif Al-Syariah: Jurnal Ekonomi dan Perbankan Syariah, 6(3), 886-912. doi:http://dx.doi.org/10.30651/jms.v6i3.12034

Copyright (C) 2021, Jurnal Masharif Al-Syariah: Jurnal Ekonomi dan Perbankan Syariah

http://journal.um-surabaya.ac.id/index.php/Mas/index

This article is licensed under a Creative Commons Attribution-NonCommercial 4.0 International License. 


\section{Abstrak}

Tujuan dari penelitian ini adalah menggali informasi tentang tata kelola keuangan, kebijakan dan sistem pemberdayaan yang dilakukan oleh pemerintah desa terkait, memetakan kendala dari pelaksanaan pemberdayaan UMKM di kawasan Desa Wisata tersebut, kemudian membuat pola/model yang tepat untuk pemberdayaan UMKM di kawasan Desa Wisata di Kabupaten Gresik. Metode yang digunakan dalam penelitian ini adalah kualtitatif dengan harapan dapat menggali lebih dalam informasi yang diperlukan guna menjawab tujuan dari penelitian. Obyek penelitian ini adalah Desa Sekapuk Gresik yang dikenal dengan sebutan desa miliarder. Hasil penelitian menunjukkan bahwa pemberdayaan UMKM di Desa Wisata Sekapuk berasal dari pengelolaan PKK yang bersifat mandiri. Sinergi antara PKK dan Pemerintah Desa menjadi tonggak kemandirian kebijakan dan sistem pengelolaan pemberdayaan UMKM. Peran Pemerintah Desa memberikan fasilitas dan stimulasi untuk kemandirian keberlangsungan UMKM dibawah PKK. Sistem bagi hasil menjadi cara yang efektif untuk mendorong pertumbuhan UMKM yang disinergikan dengan pengelolaan kawasan wisata.

Kata kunci: Model Pemberdayaan UMKM, Desa Wisata

\section{PENDAHULUAN}

Peran destinasi wisata terhadap Pendapatan Asli Daerah terutama penduduk setempat sangatlah besar. Banyak peluang usaha yang muncul dengan munculnya tujuan Destinasi Wisata. Dari pengembangan destinasi wisata dapat memunculkan maupun meningkatkan peran UMKM di wilayah sekitar. Upaya mendongkrak industri pariwisata tidak boleh melupakan pengembangan Usaha Mikro Kecil dan Menengah (UMKM) yang menjadi salah satu penyokongnya. Saat ini upaya pengembangan UMKM diterjemahkan dalam kebijakan pemerintah melalui 3 (tiga) program prioritas Kementerian Koperasi dan UMKM yaitu program pengembangan koperasi dan UKM, akses pembiayaan bagi koperasi dan UMKM, dan pemberdayaan UMKM melalui gerakan kewirausahaan nasional (Rahayu, 2017). Kebijakan lain yang juga menarik untuk dibahas adalah alokasi dana desa yang saat ini dapat dipergunakan untuk penguatan ekonomi lokal dan peningkatan sumber daya manusia termasuk salah satunya adalah pengembangan UMKM.

Berbagai upaya dan strategi nyata dilakukan beberapa pihak dalam mengembangkan UMKM. Melalui program CSR (Corporate Social 
Responsibility) perusahaan BUMN Indonesia bernama Program Rumah Kreatif BUMN (RKB), UMKM diberikan pembinaan dalam meningkatkan kapabilitas pengembangan produk dan pemasaran (Sinaga, 2017). Melalui RKB, UKM akan dibekali kemampuan untuk meningkatkan daya saing, baik dari aspek manajemen usaha, keterampilan, maupun pemasarannya, sehingga siap memasuki era globalisasi dan digitalisasi. Upaya lain adalah dengan membentuk suatu pusat layanan usaha terintegrasi bagi UMKM yang bernama PLUT (Pusat Layanan Usaha Terpadu) untuk mengakses 7 (tujuh) jenis layanan yaitu konsultasi bisnis, pendampingan atau monitoring bisnis, fasilitasi akses pembiayaan, pemasaran dan promosi, pelatihan bisnis, networking, dan terkahir adalah pustaka entrepreneur (Supriyanto, 2018)

Menurut Ketua Badan Perencanaan Pembangunan Nasional (Bappenas), Suharso Monoarfa yang dikutip dalam Tribunnews Jakarta (11 April 2021), terdapat 5 isu utama dalam pengembangan UMKM. Antara lain 1)Perbedaan definisi UMKM antara lembaga, 2)Jumlah UMKM yang besar, namun belum seimbang dengan kontribusniya pada Produk Domestik Bruto (PDB), 3)Masih rendahnya jumlah UMKM yang terjalin dalam kemitraan, 4)Akses pembiayaan UMKM yang masih rendah, 5)Rendahnya pemanfaatan teknologi dalam menjalankan usahanya. (https://www.tribunnews.com/nasional/2021/02/19/bappenas-besarnyajumlah-umkm-belum-seimbang-dengan-kontribusi-pada-pdb)

Secara lebih spesifik, permasalahan dasar yang dihadapi UMKM adalah: Pertama, kelemahan dalam memperoleh peluang pasar dan memperbesar pangsa pasar. Kedua kelemahan dalam struktur permodalan dan keterbatasan untuk memperoleh sumber sumber permodalan yang memadai. Ketiga, kelemahan di bidang organisasi dan manajemen sumber daya manusia. Keempat, keterbatasan jaringan usaha kerjasama antar pengusaha kecil (sistem informasi pemasaran). Kelima, iklim usaha yang kurang kondusif, karena persaingan yang saling mematikan. Keenam, pembinaan yang telah dilakukan masih kurang 
terpadu dan kurangnya kepercayaan serta kepedulian masyarakat terhadap usaha kecil. (Kuncoro, 2009 dalam Ahmad,2018)

Berdasarkan pada data Kementerian Koperasi dan UKM Republik Indonesia,pada tahun 2021 jumlah UMKM yang terdaftar di Kabupaten Gresik sebanyak 170.848 UKM (www.umkm.depkop.go.id). UKM tersebut ada yang berada di kawasan desa wisata, dan ada yang tersebar di luar kawasan desa wisata. Saat ini Kabupaten Gresik sedang gencargencarnya mengembangkan Tujuan Destinasi Wisata baru yang fokus pada pengembangan Desa Wisata. Beberapa desa wisata tersebut antara lain Selo Tirto Giri (Setigi) di Desa Sekapuk, Eduwisata Lontar Sewu di Desa Hendrosari, Mangrove Ujung Pangkah di Desa Banyu Urip, Telaga Ngipik di Desa Ngipik, Bukit Larangan di Desa Prupuh, Wisata Alam Gosari (Wagos) di Desa Gosari, dan masih banyak destinasi wisata lainnya. Dengan adanya destinasi wisata baru tersebut akan menambah jumlah UMKM yang terdaftar di Kabupaten Gresik.

Pandemi COVID-19 berdampak pada anjloknya penjualan dan pendapatan para UMKM di Desa Wisata. Namun, platform digital diklaim cukup membantu mereka untuk tetap bertahan. Pandemi telah membatasi orang untuk berwisata dan ini berdampak pada bisnis para pelaku UMKM di sektor pariwisata tersebut. Namun di masa pandemi ini, justru dimanfaatkan oleh para pengelola desa wisata untuk mempersiapkan diri. Mereka memanfaatkan masa ini untuk membenahi banyak hal. Termasuk mempersiapkan wisata desa yang nyaman dan aman sesuai protokol kesehatan, tanpa harus merusak identitas desa, kearifan lokal, dan keasliannya serta menerapkan sistem keuangan termasuk pembelian tiket masuk secara online. Sedangkan untuk UMKM diberikan juga akses online diluar kawasan wisata.

Beberapa pembenahan dilakukan oleh pengelola desa wisata yang disesuaikan dengan kebijakan pemerintah desa setempat. Mulai dari sistem keuangan dan perpajakan, sistem pemberdayaan baik dari segi manajemen usaha sampai pada pengetatan protokol kesehatan. Berdasarkan sudut pandang diatas, peneliti bermaksud memetakan 
kendala dari pemberdayaan UMKM di kawasan Desa Wisata tersebut baik dari segi keuangan maupun kebijakan pemerintah setempat, kemudian membuat pola/model yang tepat untuk pemberdayaan UMKM di kawasan Desa Wisata di Kabupaten Gresik

\section{KAJIAN PUSTAKA}

UMKM

UMKM adalah usaha perdagangan yang dikelola oleh badan usaha atau perorangan yang merujuk pada usaha ekonomi produktif sesuai dengan kriteria yang ditetapkan oleh Undang-Undang Nomor 20 Tahun 2008. Berdasarkan Undang-Undang Nomor 20 Tahun 2008 tentang Usaha Mikro, Kecil dan Menengah (UMKM) ada beberapa kriteria yang dipergunakan, yakni sebagai berikut.

a. Usaha Mikro : Usaha Mikro adalah usaha produktif milik perorangan atau badan usaha perorangan yang memiliki kriteria usaha mikro dengan asset maximal 50 juta rupiah dan omzet maksimal 300 juta rupiah.

b. Usaha Kecil : Usaha Kecil adalah usaha ekonomi produktif yang berdiri sendiri, yang dilakukan oleh orang perorangan atau badan usaha yang bukan merupakan anak perusahaan atau bukan cabang perusahaan yang dimiliki, dikuasai, atau menjadi bagian baik langsung maupun tidak langsung dari usaha menengah atau usaha besar. Kriteria usaha kecil ini memiliki asset lebih dari 50 juta rupiah dengan omzet lebih dari 300 juta sampai 2,5 milyar rupiah.

c. Usaha Menengah: Usaha Menengah adalah usaha ekonomi produktif yang berdiri sendiri, yang dilakukan oleh orang perseorangan atau badan usaha yang bukan merupakan anak perusahaa atau bukan cabang perusahaan yang dimilki, dikuasai atau menjadi bagianbaik langsungmaupun tidak langsung dari usaha kecil atau usaha besar. Kriteria usaha menengah ini memiliki asset lebih dari 500 juta rupiah sampai 10 milyar rupiah dan omzet lebih dari 2,5 milyar sampai 50 milyar rupiah

Menurut Partomo (dalam Al Firmansyah 2018), beberapa keunggulan 
UKM terhadap usaha besar antara lain adalah sebagai berikut:

a. Inovasi dalam teknologi yang telah dengan mudah terjadi dalam pengembangan produk.

b. Hubungan kemanusiaan yang akrab di dalam perusahaan kecil.

c. Kemampuan menciptakan kesempatan kerja cukup banyak atau penyerapannya terhadap tenaga kerja.

d. Fleksibelitas dan kemampuan menyesuaikan diri terhadap kondisi pasar yang berubah dengan cepat dibanding dengan perusahaan besar yang pada umumnya birokrasi.

e. Terdapatnya dinamisme manajerial dan peran kewirausahaan

\section{Desa Wisata}

Ricardson dan Fluker (2004) menjelaskan bahwa destinasi wisata adalah sebuah tempat yang dikunjungi secara signifikan dalam sebuah perjalanan dengan beberapa bentuk batas aktual yang dirasakan.

Desa wisata merupakan pengembangan suatu wilayah desa yang pada dasarnya tidak merubah apa yang sudah ada akan tetapi lebih cenderung kepada pengembangan potensi desa yang ada dengan melakukan pemanfaatan kemampuan unsur- unsur yang ada di dalam desa yang berfungsi sebagai atribut produk wisata dalam skala yang kecil menjadi rangkaian aktivitas atau kegiatan pariwisata dan mampu menyediakan serta memenuhi serangkaian kebutuhan perjalanan wisata baik dari aspek daya tarik maupun sebagai fasilitas pendukung (Muljadi,2012)

Desa Wisata adalah sebuah kawasan perdesaan yang memiliki beberapa karakteristik khusus untuk menjadi daerah tujuan wisata. $\mathrm{Di}$ kawasan ini, penduduknya masih memiliki tradisi dan budaya yang relatif masih asli. Selain itu, beberapa faktor pendukung seperti makanan khas, sistem pertanian, dan sistem sosial turut mewarnai sebuah kawasan desa wisata. Di luar faktor-faktor tersebut, alam dan lingkungan masih merupakan salah satu faktor terpenting dari sebuah kawasan tujuan wisata (Zakaria \& Dewi Suprihardjo, 2014) 


\section{Tinjauan Desa Wisata}

a. Desa Terbelakang atau Desa Swadaya Desa terbelakang adalah desa yang kekurangan sumber daya manusia atau tenaga kerja dan juga kekurangan dana sehingga tidak mampu memanfaatkan potensi yang ada di desanya. Biasanya desa terbelakang berada di wilayah yang terpencil jauh dari kota, taraf berkehidupan miskin dan tradisional serta tidak memiliki sarana dan prasaranan penunjang yang mencukupi.

b. Desa Sedang Berkembang atau Desa Swakarsa Desa sedang berkembang adalah desa yang mulai menggunakan dan memanfaatkan potensi fisik dan nonfisik yang dimilikinya tetapi masih kekurangan sumber keuangan atau dana. Desa swakarsa belum banyak memiliki sarana dan prasarana desa yang biasanya terletak di daerah peralihan desa terpencil dan kota. Masyarakat pedesaan swakarsa masih sedikit yang berpendidikan tinggi dan tidak bermata pencaharian utama sebagai petani di pertanian saja serta banyak mengerjakan sesuatu secara gotong royong.

c. Desa Maju atau Desa Swasembada Desa maju adalah desa yang berkecukupan dalam hal sdm / sumber daya manusia dan juga dalam hal dana modal sehingga sudah dapat memanfaatkan dan menggunakan segala potensi fisik dan non fisik desa secara maksimal. Kehidupan desa swasembada sudah mirip kota yang modern dengan pekerjaan mata pencarian yang beraneka ragam serta sarana dan prasarana yang cukup lengkap untuk menunjang kehidupan masyarakat pedesaan maju.

Pengembangan pariwisata pedesaan didorong oleh tiga faktor. Pertama, wilayah pedesaan memiliki potensi alam dan budaya yang relatif lebih otentik daripada wilayah perkotaan, masyarakat pedesaan masih menjalankan tradisi dan ritual-ritual budaya dan topografi yang cukup serasi. Kedua, wilayah pedesaan memiliki lingkungan fisik yang relatif masih asli atau belum banyak tercemar oleh ragam jenis polusi dibandingankan dengan kawasan perkotaan. Ketiga, dalam tingkat tertentu 
daerah pedesaan menghadapi perkembangan ekonomi yang relatif lambat, sehingga pemanfaatan potensi ekonomi, sosial dan budaya masyarakat lokal secara optimal merupakan alasan rasional dalam pengembangan pariwisata pedesaan

\section{Konsep PKK}

PKK singkatan dari Pembinaan Kesejahteraan Keluarga, adalah organisasi kemasyarakatan yang memberdayakan wanita untuk turut berpartisipasi dalam pembangunan Indonesia.

\section{Visi}

Terwujudnya keluarga yang beriman dan bertaqwa kepada Tuhan Yang Maha Esa, berakhlak mulia dan berbudi luhur, sehat sejahtera lahir dan batin.

\section{Misi}

1. Meningkatkan pembentukan karakter keluarga melalui penghayatan, pengamalan pancasila, kegotong royongan serta keseteraan dan keadilan gender.

2. Meningkatkan pendidikan dan ekonomi keluarga melalui berbagai upaya keterampilan dan pengembangan koperasi.

3. Meningkatkan ketahanan keluarga melalui pemenuhan pangan, sandang dan perumahan sehat dan layak huni.

4. Meningkatkan derajat kesehatan keluarga, kelestarian lingkungan hidup serta perencanaan sehat.

5. Meningkatkan pengelolaan gerakan PKK meliputi kegiatan pengorganisasian dan peningkatan sumber daya manusia.

\section{Tujuan}

Gerakan PKK bertujuan memberdayakan keluarga untuk meningkatkan kesejahteraan menuju terwujudnya keluarga yang beriman dan bertaqa kepada Tuhan Yang Maha Esa, berakhlak mulia dan berbudi luhur, sehat sejahtera lahir dan batin. 


\section{Sasaran}

Sasaran Gerakan PKK adalah keluarga, baik di pedesaan maupun perkotaan yang perlu ditingkatkan dan dikembangkan kemampuan dan kepribadiannya, dalam bidang :

- Mental spiritual menjadi sikap dan perilaku sebagai insan hamba Tuhan anggota masyarakat dan warga yang dinamis serta bermanfaat, berdasarkan Pancasila dan Undang-Undang dasar 1945.

- Fisik material meliputi pangan, sandang, papan, kesehatan, kesempatan kerja yang layak serta lingkungan yang sehat dan lestari melalui peningkatan pendidikan, pengetahuan, dan keterampilan.

Program PKK adalah 10 Program Pokok PKK, yaitu:

- Penghayatan dan Pengamatan Pancasila

- Gotong Royong

- Pangan

- Sandang

- Perumahan dan Tata Laksana Rumah Tangga

- Pendidikan dan Keterampilan

- Kesehatan

- Pengembangan Kehidupan Berkoperasi

- Kelestarian Lingkungan Hidup

- Perencanaan Sehat

\section{Strategi Pemberdayaan Umkm}

Menurut Mardikanto dan Soebiato (2013) secara konseptual strategi sering diartikan dengan beragam pendekatan. Salah satu pendekatan yang ada adalah Stretegi sebagai suatu kegiatan, strategi merupakan upayaupaya yang dilakukan setiap individu, organisasi, atau perusahaan untuk memenangkan perusahaan persaingan, demi tercapainya tujuan yang diharapkan atau telah ditetapkan.

Pengembangan UKM Husband and Purnendu dalam Tambunan 
(2012) menjelaskan tentang krusialnya pengembangan UKM karena mempunyai peranan utama dalam pertumbuhan ekonomi sebuah negara. Selain itu, dijelaskan dalam penelitiannya Winarni (2006) dan Situmorang (2008) menyatakan permasalahan yang sering dialami UKM berupa: a) kurangnya modal, b) pemasarannya sulit, c) struktur organisasinya sederhana serta pembagian kerjanya tidak baku, d) kualitas manajemennya rendah, e) SDM terbatas dan kualitasnya rendah, g) kebanyakan tidak mempunyai laporan keuangan, h) aspek legalitas lemah serta j) rendahnya kualitas teknologi

Hafsah (2004) menjelaskan bahwa upaya yang dapat dilakukan untuk menghadapi permasalahan dalam pengembangan UKM yaitu: 1) penciptaan iklim usaha yang kondusif, 2) bantuan permodalan, 3) perlindungan usaha, 4) pengembangan kemitraan, 5) pelatihan, 6) membentuk lembaga khusus, 7) memantapkan asosiasi, 8) mengembangkan promosi dan 9) mengembangkan kerjasama yang setara.

\section{Strategi Pemberdayaan Umkm Di Desa Wisata}

Strategi pemberdayaan ekonomi desa wisata menurut Mubyarto dapat dilihat dari tiga sisi yaitu:

a. Menciptakan suasana atau iklim yang memungkinkan potensi masyarakat berkembang. Titik tolak pemikirannya adalah pengenalan bahwa setiap manusia dan setiap masyarakat memiliki potensi yang dapat dikembangkan. Hakikat kemandirian dan keberadaan rakyat adalah keyakinan bahwa rakyat memiliki potensi untuk mengorganisasi dirinya sendiri dan potensi kemandirian tiap individu perlu diberdayakan.

b. Memperkuat potensi ekonomi atau daya yang dimiliki masyarakat dengan menerapkan langkah-langkah pemberdayaan melalui aksiaksi yang nyata seperti menyediakan sarana dan prasarana fisik maupun sosial, pendidikan, pelatihan, peningkatan kesehatan, pemberian modal, informasi, dalam rangka memperkuat potensi ekonomi dan memanfaatkan peluang-peluang ekonomi yang dapat diakses oleh masyarakat lapisan paling bawah. 
c. Mengembangkan ekonomi rakyat juga memiliki arti melindungi rakyat, membela kepentingan masyarakat lemah, mencegah terjadinya persainganyang tidak seimbang dan juga praktik eksploitasi yang kuat terhadap yang lemah melalui adanya kesepakatan yang jelas untuk melindungi golongan yang lemah

\section{Indikator Keberhasilan Pemberdayaan UMKM}

Untuk mengetahui fokus dan tujuan pemberdayaan maka perlu diketahui berbagai indikator keberdayaan yang dapat menunjukan seseorang itu berdaya atau tidak. Schuler, Hashemi dan Riley yang dikutip oleh Edi Suharto (2009) mengembangkan delapan indikator pemberdayaan, yang mereka sebut sebagai empowerment index atau indeks pemberdayaan. Keberhasilan pemberdayaan masyarakat dapat dilihat dari keberdayaan mereka dalam kemampuan ekonomi, kemampuanmengakses manfaat kesejahteraan, dan kemampuan kultural dan politis

a. Kebebasan mobilitas, kemampuan individu untuk pergi keluar rumah atau wilayah tempat tinggalnya. Tingkat mobilitas ini dianggap tinggi jika individu mampu pergi sendirian.

b. Kemampuan membeli komoditas kecil, kemampuan individu untuk membeli barang-barang pokok kebutuhan sehari-hari (beras, minyak, bumbu), kebutuhan dirinya (sabun, sampo, peralatan makeup).

c. Kemampuan membeli komoditas besar, kemampuan individu untuk membeli barang sekunder atau tersier, seperti lemari pakaian, televisi, radio, koran, majalah dan lain sebagainya

d. Terlibat dalam keputusan keputusan rumah tangga, misalnya keputusan merenovasi rumah, membeli kambing untuk diternak. Membuat keputusankeputusan sendiri maupun secara musyawarah dilakukan secara kebersamaan dan kesetaraan dalam keluargae.

e. Kebebasan relatif dari dominasi keluarga, tidak adanya diskriminasi dalam keluarga yang menimbulkan ketidakadilan dan pelarangan 
maupun kekerasan.

f. Kesadaran hukum dan politik, keterlibatan individu dalam pengambilan peran dalam proses budaya, hukum dan politik. Misalnya mengetahui peran pemerintah desa atau kelurahan

g. Keterlibatan bersama untuk meningkatkan kesejahteraan publik, tindakan bersama untuk membela orang lain menghadapi perlakuan salah dalam keluarga dan masyarakat

\section{METODOLOGI PENELITIAN}

\section{Metode Penelitian}

Metode penelitian yang digunakan dalam penelitian ini adalah metode kualitatif. Alasan peneliti memilih metode kualitatif adalah untuk memahami situasi yang akan dikaji secara mendalam, menjawab pertanyaan Strategi Pemberdayaan UMKM di Desa Wisata. Untuk memahami sebuah lingkungan sosial yang spesifik, peneliti menyelami pengalaman subjektif para pelakunya. Penelitian interpretatif tidak menempatkan objektivitas sebagai hal terpenting, melainkan mengakui bahwa demi memperoleh pemahaman mendalam, maka subjektivitas para pelaku harus digali sedalam mungkin hal ini memungkinkan terjadinya trade-off antara objektivitas dan kedalaman temuan penelitian (Efferin, 2004)

Secara garis besar alur/proses penelitian yang digunakan dalam penelitian ini dapat dilihat pada gambar: 
Kajian Pustaka :

- Definisi dan Karakteristik UMKM

- Desa Wisata

- Tata Kelola Keuangan dan Perpajakan UMKM

- Pemberdayaan UMKM di Desa Wisata

Observasi :

- Tata Kelola Keuangan dan Perpajakan

- Kebijakan pemerintah daerah

\section{Lokasi Penelitian}

Penelitian ini dilakukan di Desa Wisata Sekapuk, Kabupaten Gresik, Jawa Timur.

\section{Pemilihan Informan}

Penelitian ini memerlukan informan yang mempunyai pemahaman dan pengalaman langsung yang berhubungan dengan pemberdayaan umkm di desa wisata.

Adapun informan yang dipilih :

1. Pihak Pengelola Desa Wisata

2. Pelaku UMKM di Desa Wisata

3. Warga setempat sekitar Desa Wisata

4. Pemerintah Desa Setempat

Wawancara:

- Pengelola Desa Wisata

- Pelaku UMKM

- Warga setempat desa wisata

Pengumpulan Data

Penarikan

Kesimpulan

Model Strategi

Gambar 1.Kerangka Pemikiran Penelitian 


\section{Teknik Analisis Data}

Teknik analisis data lebih banyak dilakukan bersamaan dengan pengumpulan data. Analisis data yang dilakukan pada penelitian ini adalah interaktif melalui proses reduction, data display, dan verification (Miles dan Huberman dalam Sugiyono,2019). Tahapan dalam teknik analisis data adalah sebagai berikut :

\section{a. Proses Reduksi Data}

Dalam proses ini, peneliti menelaah seluruh data yang didapat dari sumber informasi. Data tersebut dikaji dan dirangkum untuk setiap dokumen maupun hasil wawancara. Kemudian mereduksi data dengan memilih data atas dasar tingkat relevansi, menyusun data dalam satuan yang sejenis, kemudian menyederhanakan data kasar ke dalam catatan lapangan.

b. Penyajian Data

Peneliti menyusun data yang relevan dari catatan lapangan dan menampilkannya dalam bentuk informasi yang dapat dimengerti oleh pembaca tentang apa yang terjadi dan ditindaklanjuti untuk mencapai tujuan yang diinginkan.

c. Verifikasi

Setelah menampilkan hasil analisa data yang mengarah pada kesimpulan yang bersifat terbuka, peneliti melakukan triangulasi (sumber,teknik,dan waktu pengumpulan data), diskusi dengan teman sejawat, menerima masukan dari pembaca, memaknai analisis spesifik sehingga menghasilkan kesimpulan yang jelas.

Menurut Sugiyono Uji Keabsahan Data dalam penelitian kualitatif meliputi uji validitas internal/ credibility, validitas eksternal/ transferability, reliabilitas/dependability, dan obyektivitas/konfirmability. (Sugiyono,2019)

a. Uji kredibilitas data atau kepercayaan terhadap data hasil penelitian kualitatif antara lain dilakukan dengan perpanjangan pengamatan (kembali kelapangan setelah observasi selesai), triangulasi (sumber, teknik, dan waktu pengumpulan data), diskusi dengan teman sejawat, analisis kasus negatif, menggunakan bahan 
referensi (alat bantu rekam,foto,dan dokumen) dan membercheck (konfirmasi kembali kepada narasumber).

b. Uji transferability dilihat dari hingga mana hasil penelitian dapat diterapkan dalam situasi lain. Namun nilai transfer ini bergantung pada pemakai. Dengan kata lain bila pembaca memperoleh gambaran yang jelas tentang suatu hasil penelitian dan memutuskan dapat atau tidaknya mengaplikasikan hasil penelitian tersebut ditempat lain, maka laporan penelitian tersebut memenuhi standar transferabilitas (Sanafiah Faisal,1990 dalam Sugiyono,2010).

c. Uji dependability dilakukan dengan melakukan audit terhadap keseluruhan proses penelitian. Apakah penelitian benar-benar dilakukan di lapangan atau sekedar mendapatkan data tanpa observasi. Hal ini dibuktikan dengan "jejak aktivitas lapangan peneliti" yang dipantau auditor atau konsultan (pembimbing). Rekam jejak tersebut berupa catatan di lapangan, bukti rekaman, bukti foto dokumentasi, dokumen, dan surat keterangan telah melakukan penelitian dari Obyek yang diteliti.

d. Uji Konfirmability mirip dengan uji dependability, sehingga pengujiannya dapat dilakukan secara bersamaan. Uji konfirmability menguji hasil penelitian dikaitkan dengan proses yang dilakukan di lapangan dalam bentuk pemaparan peneliti bagaimana proses ketika di lapangan

\section{. HASIL DAN PEMBAHASAN}

\section{Profil Desa Sekapuk}

Sekapuk adalah sebuah desa di Kecamatan Ujung Pangkah Kabupaten Gresik provinsi Jawa Timur. Mayoritas mata pencaharian penduduk Sekapuk adalah penambang bukit kapur untuk dijadikan bata putih. Jumlah Penduduk Desa Sekapuk sebanyak 4.673 orang, jumlah Laki - laki sebanyak 2.324 orang, Perempuan sebanyak 2.349 orang dengan tingkat kepadatan Penduduk 15,7 c/Luas Desa, Mayoritas penduduk Desa Sekapuk beragama muslim atau seluruhnya menganut agama Islam 
Adapun Visi dan Misi pemerintahan desa Sekapuk adalah sebagai berikut VISI: Mewujudkan masyarakat yang berperadaban, berkeadilan, dan sejahtera

\section{MISI}

1. Meningkatkan pembangunan fisik \& tata ruang yang baik, indah, dan modern

2. Mengembangkan sumber-sumber ekonomi desa dan memberdayakan ekonomi masyarakat.

3. Mengoptimalkan sistem pemeritahan yang tanggap dan tertib dalam melayani.

4. Mendorong berkembangnya pendidikan dan kreatifitas

5. Membangkitkan budaya dan kearifan lokal yang baik.

6. Menjaga dan melestarikan nilai-nilai keagamaan yang berkembang di masyarakat.

7. Menjamin kesamaan kedudukan dan melindungi hak-hak masyarakat.

Dalam menjalankan pengelolaan desa, Sekapuk berada pemerintahan desa yang dikepalai oleh Bapak Abdul Halim. Adapun struktur organisasi sebagaimana gambar berikut :

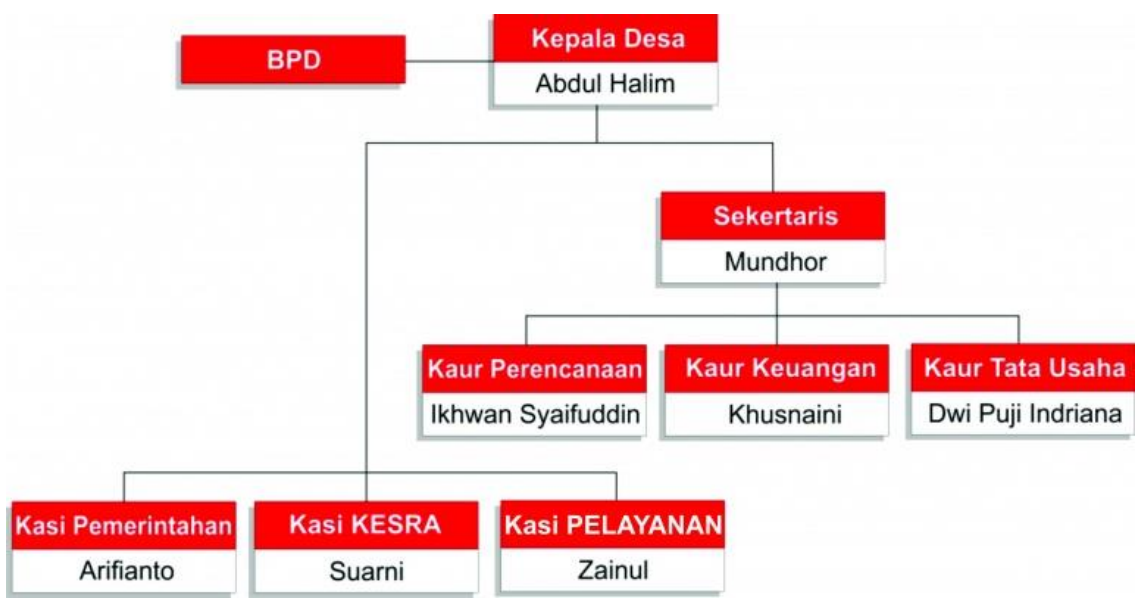

Gambar 2.Struktur Organisasi Pemdes Sekapuk

IDM yaitu program yang diterbitkan Badan Pusat Statistik. IDM merupakan indeks komposit yang dibangun dari dimensi sosial, ekonomi 
dan budaya. Nilai range yang diperoleh menjadi pembatas status setiap Desa, sehingga ditetapkan lima klasifikasi status desa yaitu:

1.Desa Sangat Tertinggal: $<0,491$.

2.Desa Tertinggal: $>0,491$ dan $<0,599$.

3.Desa Berkembang: $>0,599$ dan $<0,707$.

4.Desa Maju: $>0,707$ dan $<0,815$.

5.Desa Mandiri: > 0,815.

Pada tahun 2003, Desa Sekapuk merupakan desa dengan status tertinggal. Desa tertinggal didefinisikan sebagai desa-desa yang memiliki nilai skor sampai maksimal 32. Kenyataannya, menurut Podes 2003 jumlah desa tertinggal berada pada skor 24- 32. Kini status Desa Sekapuk berada pada IDM MANDIRI. Sebagaimana pernyataan Bapak Abdul halim,

"Dulu tahun 2003 Sekapuk masuk pada Desa Tertinggal, kemudian tahun 2017 IDM kami berubah menjadi Desa berkembang karena kami mulai melakukan pembenahan dari pengelolaan data kependudukan dan pemetaan penduduk. Setahun kemudian kami berhasil mencapai IDM Desa maju dengan disulapnya tambang kapur menjadi wisata desa. Dan alhamdulillah di tahun 2021 ini IDM kami sudah berada pada IDM mandiri"

Tidak ada yang mengira pencapaian yang didapatkan Desa Sekapuk ini, terlebih lagi di tengah pandemi COVID-19. Padahal sebelumnya Desa Sekapuk tercatat sebagai desa termiskin, sekaligus tertinggal di Kabupaten Gresik. Bapak Abdul Halim menyatakan,

"kita bersyukur sebagai warga Sekapuk terutama, mengingat kemampuan PADes kita, dan juga harus menyadari pentingnya gotongroyong, terbukti sampai saat ini kebijakan DD yang sudah diatur dari Pusat dan kondisi pandemi yang tak kunjung usai tapi desa kita tetep membangun dengan cara dan konsep yang sangat tepat. Dari sini perlunya pikiran "out of the box"

Keberhasilan Desa Sekapuk berawal dari bekas galian tambang kapur yang disulap menjadi destinasi wisata yang menarik. Wahana ini bernama Selo Tirto Giri (Setigi) yang dibuka pada 2019. Menariknya, wahana ini dikerjakan dari hasil patungan warga dan pemerintah desa Berkat 
keberhasilannya menyulap tempat wisata tersebut, membuat pemasukan Desa Sekapuk pelan-pelan terus meningkat. Mengutip dari laman desa.lokadata; pada 2018 Pendapatan Asli Desa (PADes) Desa Sekapuk mencapai sekitar Rp575,7 juta. Sedangkan pada 2019 ada peningkatan yang cukup signifikan, yaitu Rp929 juta. Bahkan, hingga Oktober 2020 pendapatannya makin melejit, yaitu mencapai Rp1,4 miliar.

Seperti pendapat Zakaria dan Dewi (2014), beberapa faktor pendukung seperti makanan khas, sistem pertanian, dan sistem sosial turut mewarnai sebuah kawasan desa wisata. Di luar faktor-faktor tersebut, alam dan lingkungan masih merupakan salah satu faktor terpenting dari sebuah kawasan tujuan wisata .

Satu hal yang menarik dari proses pembangunan desa ini adalah, setiap kegiatan atau program yang dijalankan dilakukan sepenuhnya secara mandiri. Desa Sekapuk tidak menggunakan bantuan pemerintah daerah, maupun bantuan dana Corporate Social Responsibility (CSR) dari sebuah perusahaan. Semua dana yang didapatkan adalah hasil dari patungan warga Desa Sekapuk, dan pemerintah desa yang kemudian dikumpulkan ke BUMDes.

"Semua kegiatan yang kami jalankan dilakukan sepenuhnya secara mandiri. Kami tidak menggunakan bantuan pemerintah daerah, maupun bantuan dana CSR dari perusahaan. Semua dana yang didapatkan adalah hasil dari patungan warga Desa Sekapuk,bahkan setiap warga desa diangkat langsung menjadi investor untuk mengembangkan Desa Sekapuk. Mengapa? Karena saya tidak ingin warga jadi pembantu, jadi buruh, ataupun jadi KACUNG didesa sendiri. Jika saya hanya berambisi yang penting bangun, dan sependapat dengan mereka yang usul untuk investor masuk dalam pembangunan wisata maka selesailah kalian saat ini jadi buruh investor. kunci keberhasilan membangun Desa Sekapuk adalah "GILA"; Gagasan, Ide, Langsung, dan Aksi. Hal ini dapat dilihat dari bagaimana perangkat desa membuktikan kerja nyata, dan menjalin hubungan yang baik dengan warganya.", tutur Kepala Desa Sekapuk

\section{UMKM Desa Sekapuk}

Saat ini pemerintah fokus pada program SDGs (Sustainable Development Goals). Adapun konsep dari SDGs desa adalah upaya terpadu mewujudkan Desa tanpa kemiskinan dan kelaparan, Desa ekonomi tumbuh merata, Desa peduli kesehatan, Desa peduli lingkungan, Desa 
peduli pendidikan, Desa ramah perempuan, Desa berjejaring, dan Desa tanggap budaya untuk percepatan kepada pencapaian, pembangunan berkelanjutan. Dalam rangka mewujudkan hal tersebut, maka perlu dikembangkannya UMKM. Mengingat pentingnya UMKM sebagai tulang punggung perekonomian Indonesia bangkit dimasa pandemi, melalui UU Cipta Kerja yang memberikan berbagai kemudahan bagi para pengusaha mikro dan kecil untuk pengembangan usahanya.

Sebelum tahun 2017, Pemdes Sekapuk tidak pernah mendata maupun memberikan upaya pemberdayaan UMKM di sekitar Desa Sekapuk. Sejak tahun 2017, Pemerintah Desa Sekapuk mulai melakukan pembenahan data dan mensinergikan UMKM di Desa Sekapuk dengan program pemerintah desa. Di tahun 2020 terdata 150 UMKM warga Sekapuk sejak lahirnya wisata SETIGI. Wisata yang dibangun masyarakat kembali untuk masyarakat, terbukti 100\% karyawan-karyawati wajib berKTP Sekapuk.

BUMDes Desa Sekapuk memiliki empat jenis usaha, seperti wisata Selo Tirto Giri, PDAM, pengolahan sampah, dan tambang kapur. Dari keempat usaha tersebut, BUMDes Desa Sekapuk berhasil meraup laba bersih sebesar Rp7 miliar pada 2020. Artinya, Desa Sekapuk turut menyumbang Pendapatan Asli Desa sebesar Rp2,047 miliar. Kementerian Dalam Negeri, Kementerian Desa, dan Kementerian BUMN memberikan penghargaan kepada Desa Sekapuk yaitu "Desa Brilian Terbaik seIndonesia", karena dapat mengelola pemerintah desa dan BUMDes dengan baik. (www.kemenparekraf.go.id) 


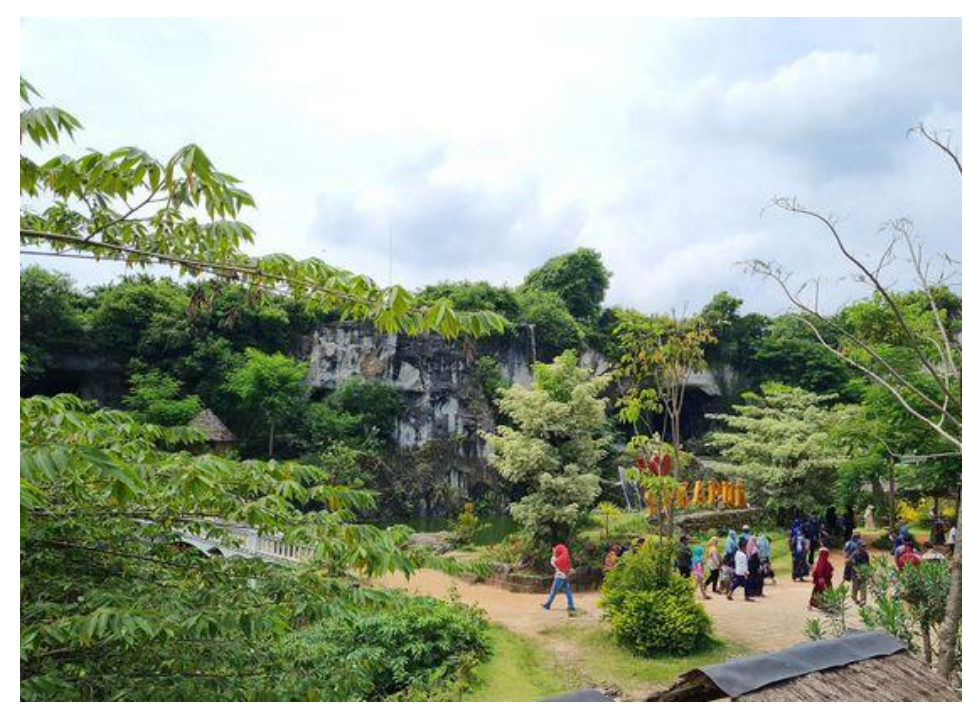

Gambar 3.Wisata Setigi

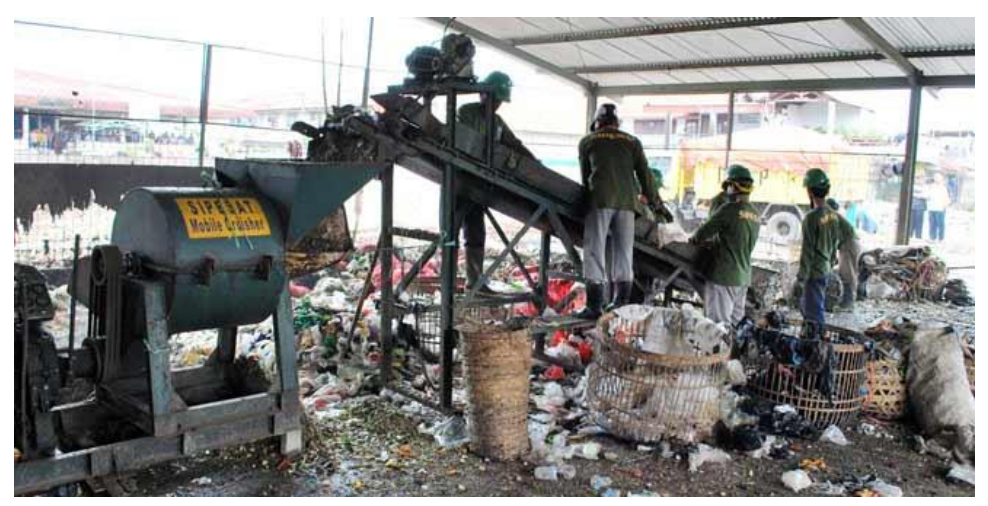

Gambar 4. Pusat Pengelolaan Sampah Sekapuk

\section{Strategi Pemberdayaan UMKM Desa Sekapuk}

Unsur terpenting dalam pembangunan desa wisata adalah keterlibatan masyarakat desa dalam setiap aspek kepariwisataan di desa tersebut. Terdapat dua indikator penting mengenai tingkat keberhasilan suatu desa wisata, diantaranya yaitu adanya kemandirian institusi-institusi lokal dan tersedianya sumber daya manusia yang memadai.

Strategi pengembangan desa wisata melalui pemberdayaan UMKM berarti melibatkan masyarakat setempat dalam upaya meningkatkan kemampuan UMKM yang sinergi dengan pengembangan desa wisata. Tujuan pengembangan tersebut adalah untuk meningkatkan daya tarik 
pengunjung dan menggerakan perekonomian masyarakat menuju yang lebih baik dan sejahtera.

Adapun strategi pengembangan tersebut ditempuh melalui pemberdayaan PKK (Program Kesejahteraan Keluarga). Dibawah naungan PKK, kelompok UMKM di Desa Sekapuk disebut "Dapur Mbok Inggih". Adapun upaya tersebut antara lain :

1. Mengembangkan wisata desa yang terdapat di Desa Sekapuk yaitu Selo Tirto Giri (SETIGI) dan Kebun Pak Inggih (KPI) untuk peluang usaha bagi UMKM

2. Memberikan pelatihan kuliner dengan mendatangkan tim ahli pangan dan chef dari restarurant maupun hotel ternama

3. Memberikan pelatihan manajemen dan pengelolaan keuangan untuk UMKM

4. Mensinergikan pengelolaan UMKM dan kegiatan PKK, baik dari segi materil maupun spiritual

5. Tidak memungut 'retribusi dari pengelolaan UMKM, namun melakukan sistem bagi hasil

Dengan strategi tersebut, maka tidak semua pengelolaan manajemen UMKM berada dibawah Bumdes Desa Sekapuk, pemberdayaan UMKM di desa Sekapuk juga disinergikan dengan kegiatan PKK. Hal ini dilakukan agar peluang kontribusi masyarakat dapat lebih besar. Apalagi dengan adanya pandemi covid'19 semakin menekan perekonomian masyarakat. Dengan dilaksanakannya strategi tersebut maka dapat mempermudah langkah, perkembangan dan perijinan UMKM Desa.

"Ditengah pandemi kita bisa sinergi terlebih urusan kebangkitan UMKM didesa kita Sekapuk hari ini bisa mengikuti tahapan perijinan, tidak hanya bisa pertahankan camilan lokal tapi justru bisa kembangkan sampai ke perijinan. Hal ini mulai bisa di ikuti dan dirasakan UMKM yang tergabung di UKM Dapur Mbok Inggih PKK", celetuk Bapak Abdul Halim 


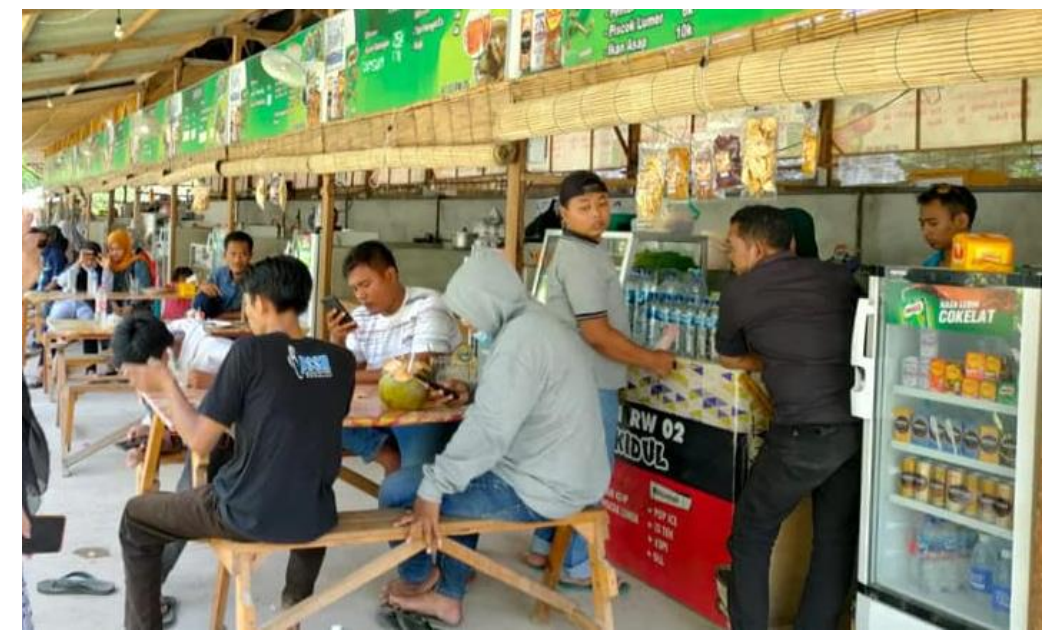

Gambar 5.Salah satu UMKM Dapur Mbok Inggih

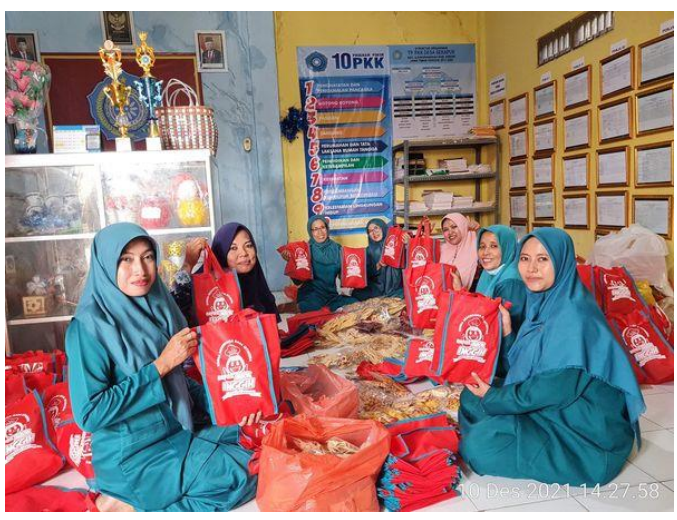

Gambar 6. Pengurus UMKM Dapur Mbok Inggih

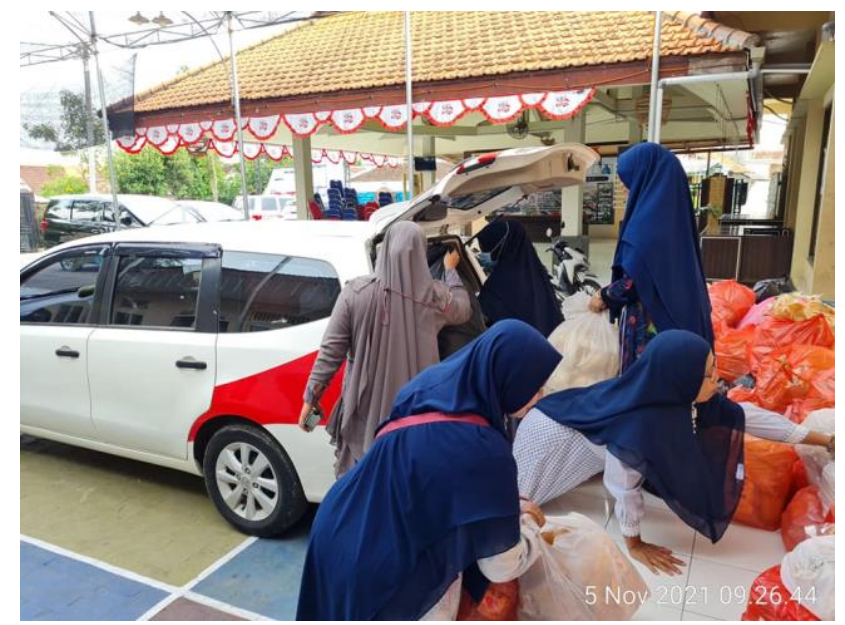

Gambar 7. Mobil Dinas UMKM Dapur Mbok Inggih 
Selain itu untuk membantu modal pengembangan Desa Wisata dan UMKM, pemerintah desa Sekapuk memberikan kesempatan kepada warga untuk menjadi investor. Ada tabungan wisata SETIGI warga untuk pembangunan wisata (Taplust Invest Wisata) baik untuk Setigi maupun KPI. Menabung Rp.10.000 selama 25 hari, sehingga akan terkumpul Rp.250.000 perbulan. Tabungan tersebut murni untuk warga, tanpa ada potongan dari bumdes sebagaimana diatur pada perkades. Keuntungan $10 \%$ dari hasil pengelolaan wisata dan UMKM diberikan kepada nasabah sebagai bentuk bagi hasilnya.

Bapak Abdul Halim menambahkan "Saya selalu menekankan kepada warga bahwa gaji tidak akan pernah cukup untuk kebutuhan, hanya rizqi yang mampu mencukupi, dan rasa syukur itulah yang mempercepat datangnya rizqi. Cerdaslah membedakan antara kebutuhan hidup dan gaya hidup. Mari bersama membangun desa, buat warga Sekapuk hususnya agar bisa sinergi bersama, ketika desa ini dinobatkan sebagai Desa Wisata, maka segera lengkapi peluang usaha, semisal Usaha aksesori, aneka camilan dan kerajinan, sampai homestay dan sebagainya."

Di kesempatan yang berbeda, Ketua PKK Desa Sekapuk Ibu Rif'atul Mubarokah menyampaikan, "Inovasi pemdes Sekapuk dalam peningkatan ekonomi baik untuk warga dan peningkatan PADES melalui wisata desa sangatlah terasa efeknya,terutama di musim liburan seperti ini,karena Wisata Setigi di bangun oleh warga dan untuk warga,tidak ketinggalan pula berdampak ke ibu2 produsen jajan dapur Mbok Inggih yang memproduksi jajanan khas desa Sekapuk yang di sinergikan di wisata sebagai oleh2 khas desa Sekapuk."

Upaya pemberdayaan UMKM dari PKK dilakukan dengan mensinergikan kegiatan PKK dan pemerintah desa. Adapun kelompok UMKM Dapur Mbok Inggih dipetakan menjadi :

1. 30 stand kuliner di masing-masing tempat wisata dimana setiap stand adalah stand dari masing-masing RT di Desa Sekapuk yang menaungi produk kuliner di setiap RT

2. Pengelolaan souvenir di Desa Sekapuk yang menjadi suplier usaha souvenir di masing-masing kelompok pembuatan souvenir di Desa Sekapuk

3. Dapur jajanan Mbok Inggih yang menjadi suplier jajanan makanan khas dan oleh-oleh wisata Desa Sekapuk dari seluruh produsen warga Sekapuk 
Program pemberdayaan UMKM Dapur Mbok Inggih juga disertai dengan Monitoring dan Evaluasi yang dilakukan setiap bulan baik dari pusat PKK desa maupun di tingkat PKK RT. Dalam 1 minggu tercatat omset Dapur Mbok Inggih mencapai Rp.150.000.000 sebagaimana disampaikan ketua PKK Desa Sekapuk, "Walaupun dengan harga ekonomis yaitu mulai Rp.5000 perbungkus jajanan Dapur Mbok Inggih berkembang pesat. Jajanan dari warga dikumpulkan di Dapur Mbok Inggih dengan 1 label yaitu Dapur Mbok Inggih. Dihitung dan dikumpulkan dari warga setiap minggunya. Bahkan kami dapat mencairkan uang warga dari produk jajanan sampai Rp.150.000.000 Iho. Alhamdulillah rezeki ibu2 produsen Dapur Mbok Inggih".

Berdasarkan indikator pemberdayaan atau empowerment index atau indeks pemberdayaan menurut Schuler, Hashemi dan Riley yang dikutip oleh Edi Suharto (2009), strategi pemberdayaan UMKM di Desa Sekapuk memenuhi beberapa indikator yaitu

1. Kebebasan mobilitas (UMKM di bawah naungan Dapur Mbok Inggih telah memiliki 2 mobil operasional dari penyisihan laba usaha)

2. Kemampuan membeli komoditas kecil (seluruh UMKM di bawah naungan Dapur Mbok Inggih telah diberikan alat untuk pengemasan secara mandiri, dan memiliki 1 label bersama bernama Dapur Mbok Inggih).

3. Kemampuan membeli komoditas besar (UMKM di bawah naungan Dapur Mbok Inggih telah memiliki dapur umum untuk menerima produk dari seluruh UMKM dan mobil)

4. Terlibat dalam keputusan bersama (UMKM di bawah naungan Dapur Mbok Inggih sudah memiliki agenda Monev)

5. Kebebasan berkeadilan (UMKM di bawah naungan Dapur Mbok Inggih memiliki kesempatan yang sama untuk berkembang dengan diberikannya kesempatan untuk semua RT).

6. Kesadaran hukum dan politik (Dapur Mbok Inggih memiliki perizinan usaha)

7. Keterlibatan bersama untuk meningkatkan kesejahteraan public (karena Dapur Mbok Inggih menaungi seluruh UMKM di Desa 
Sekapuk, maka secara otomatis ikut meningkatkan kesejahteraan publik)

Dalam penelitiannya, Winarni (2006) dan Situmorang (2008) menyatakan permasalahan yang sering dialami UKM berupa: a) kurangnya modal, b) pemasarannya sulit, c) struktur organisasinya sederhana serta pembagian kerjanya tidak baku, d) kualitas manajemennya rendah, e) SDM terbatas dan kualitasnya rendah, g) kebanyakan tidak mempunyai laporan keuangan, h) aspek legalitas lemah serta j) rendahnya kualitas teknologi

Manajemen pengelolaan UMKM Dapur Mbok inggih sudah memadai karena disinergikan dengan kegiatan PKK. Kendala umum UMKM seperti modal, pembagian kerja, kualitas SDM, laporan keuangan, dan aspek legalitas sudah berhasil diselesaikan. Namun kendala yang dihadapi UMKM Dapur Mbok Inggih adalah belum tersentuhnya pasar diluar Desa. Mereka masih mencukupi kebutuhan pasar di sekitar desa wisata Sekapuk. Belum adanya badan usaha resmi Dapur Mbok Inggih untuk bisa menjadi franchise atau merambah pasar di tingkat nasional maupun internasional. Ini dapat menjadi peluang Dapur Mbok Inggih yang menaungi seluruh UMKM di Desa Sekapuk untuk semakin meningkatkan usaha dan kesejahteraan bersama.

Bagaimanapun bentuk kebijkan yang ditempuh, pengembangan ekonomi lokal mempunyai satu orientasi, yaitu: meningkatkan jumlah dan variasi peluang kerja yang tersedia untuk penduduk lokal. Dalam mencapai hal tersebut, pemerintah daerah dan kelompok masyarakat dituntut untuk mengambil inisiatif dan bukan hanya berperan pasif saja. Setiap kebijkan dan keputusan publik dan sektor usaha, serta keputusan dan tindakan masyarakat, harus sesuai dengan orientasi pengembangan ekonomi lokal, atau sinkron dan mendukung kebijakan pengembangan ekonomi daerah yang telah dispakati bersama.

\section{KESIMPULAN DAN SARAN}

Hasil penelitian menunjukkan bahwa pemberdayaan UMKM di Desa Wisata Sekapuk merupakan konsep yang baik dalam program pemberdayaan masyarakat berbasis potensi dan kearifan nilai lokal. 
Strategi pemberdayaan UMKM berasal dari pengelolaan PKK yang bersifat mandiri. Sinergi antara PKK dan Pemerintah Desa menjadi tonggak kemandirian kebijakan dan sistem pengelolaan pemberdayaan UMKM. Peran Pemerintah Desa memberikan fasilitas dan stimulasi untuk kemandirian keberlangsungan UMKM dibawah PKK. Sistem bagi hasil menjadi cara yang efektif untuk mendorong pertumbuhan UMKM yang disinergikan dengan pengelolaan kawasan wisata

Saran untuk pengembangan strategi pemberdayaan UMKM Desa Sekapuk adalah dengan menggandeng instansi atau SDM unggul di bidang IPTEK yang mengedepankan Digital Marketing untuk memasarkan produk UMKM Dapur Mbok Inggih menuju pasar nasional bahkan di tingkat internasional.

\section{DAFTAR PUSTAKA}

Agusetyaningrum,et all. (2016). Strategi Pengembangan Usaha Kecil dan Menengah (UKM) untuk Meningkatkan Citra Kota Malang sebagai Destinasi Wisata Kuliner. Jurnal Administrasi Bisnis (JAB) 38(2),105111

Ahmad,Faizal dan E.Rahayu. (2018). Model Kemitraan dalam Pemberdayaan Usaha Mikro Pedesaan. Jurnal ilmu Kesejahteraan Sosial 19(2), 145-158

A.J, Muljadi, (2012), Kepariwisataan dan Perjalanan. Jakarta: Raja Grafindo Persada

Edi Suharto. (2009). Membangun Masyarakat Memberdayakan Rakyat. Bandung: PT Refika aditama

Kuncoro, M. (2009). DasarDasar Ekonomika Pembangunan Edisi 5, Yogyakarta: STIM YKPN.

Kuncoro, M. (2014). Metode Riset Untuk Bisnis dan Ekonomi. Edisi 4. Jakarta: Erlangga

Moleong, Lexy J. (1998). Metode Penelitian Kualitatif. Bandung: Remaja Rosdakarya.

Mubyarto. (1997). Ekonomi Rakyat Program IDT dan Demokrasi Ekonomi Indonesia. Yogyakarta: Aditya Media

Richardson, John dan Martin Fluker. (2004). Understanding and Managing Tourism. Australia: Pearson Education.

Supriyanto, B. (2018). Pemberdayaan Ukm: Pusat Layanan Usaha Terpadu Mulai Dirintis. Retrieved June 10, 2018, from http://industri.bisnis.com/read/20130426/87/1 1043/pemberdayaanukm-pusat-layananusaha-terpadu-mulai-dirinti 
Tambunan,Tulus.(2008). Usaha Mikro Kecil dan Menengah di Indonesia: Isu-Isu Penting

Undang-Undang Nomor 90 Tahun 1990 tentang Kepariwisataan

Undang-Undang Republik Indonesia No.20 Tahun 2008 tentang UMKM (Jakarta: LP3ES, 2012), hal. 11

Zakaria,et al. (2014). Konsep Pengembangan Kawasan Desa Wisata di Desa Bandungan Kecamatan Pakong. Kabupaten Pamekasan". Jurnal Teknik POMTS 3(2) 